\title{
First reproduction report of Trachemys scripta in Portugal Ria Formosa Natural Park, Algarve
}

\author{
Bruno Herlander Martins, ${ }^{1, *}$, Fábia Azevedo² and José Teixeira ${ }^{1,3}$ \\ ${ }^{1}$ CIBIO - UP / InBIO, Centro de Investigação em Biodiversidade e Recursos Genéticos da Universidade do \\ Porto. Campus Agrário de Vairão, 4485-661 Vairão, Portugal. \\ 2 RIAS - ALDEIA, Centro de Recuperação e Investigação de Animais Selvagens. Parque Natural da Ria \\ Formosa, 8700 Quelfes-Olhão, Portugal. \\ 3 CIIMAR - Interdisciplinary Centre of Marine and Environmental Research. Rua dos Bragas, 289, 4050-123 \\ Porto, Portugal. \\ * Corresponding author: bruno_herlander@hotmail.com
}

Received: 04/02/15 Accepted: 10/08/17

\begin{abstract}
First reproduction report of Trachemys scripta in Portugal - Ria Formosa Natural Park, Algarve

We report the widespread occurrence of Trachemys scripta at Ria Formosa Natural Park, in sympatric conditions with native populations of Emys orbicularis and Mauremys leprosa, and the first confirmed case of successful reproduction in Portugal. The continuous naturalization reports of this invasive species, whose distribution has expanded worldwide in the last decades, confirm the need to implement urgent management measures for nature conservation, especially given the vulnerability of Emys orbicularis populations.
\end{abstract}

Key words: invasive species, Portugal, reproduction, Trachemys scripta

\section{RESUMO}

Primeiro relatório da reprodução de Trachemys scripta em Portugal - Parque Natural da Ria Formosa, Algarve

Neste trabalho apresenta-se evidências sobre a ocorrência generalizada de Trachemys scripta no Parque Natural da Ria Formosa, em condições simpátricas com populações nativas de Emys orbicularis e Mauremys leprosa, e o primeiro caso confirmado de reprodução com sucesso em Portugal. A contínua naturalização com sucesso desta espécie invasora, cuja sua distribuição tem vindo a aumentar por todo o mundo nas últimas décadas, confirma a necessidade de implementação de medidas de gestão urgentes para a conservação da natureza, especialmente dada a vulnerabilidade das populações de Emys orbicularis.

Palavras chave: espécies invasoras, Portugal, reprodução, Trachemys scripta 


\section{INTRODUCTION}

The introduction of exotic species, and subsequent competitive interactions between these species and the native fauna, are identified as important drivers for global loss of biodiversity (Primack, 1997; Mooney et al., 2005; Hulme et al., 2009; Butchart et al., 2010). The slider turtle, Trachemys scripta, native to the eastern and central United States of America, is considered one of the world's worst invasive alien species (Lowe et al., 2000). The main cause of introduction into the wild stems from their massive trade as pets over the last decades, from turtle farms in the USA to foreign markets (Telecky, 2001). Until recently, they were legally sold in Europe as hatchlings (3-4 cm carapace length), and their owners are rarely prepared to maintain them in captivity when they start to grow (reaching up to $30 \mathrm{~cm}$ carapace length). This common situation leads to frequent releases of these animals in the wild, resulting in the introduction and establishment of many T. scripta populations into different natural freshwater ecosystems.

Currently this turtle has been reported as introduced into the wild outside its natural range throughout all continents: Europe (Luiselli et al., 1997; Miranda \& Leunda, 2010), Africa (Newberry, 1984), Asia (Chen \& Lue, 1998), Oceania (Burgin, 2006) and America (Thomson et al., 2010). Once introduced, the main requirement for its invasion is the occurrence of successful reproduction. Therefore, firm evidence about its reproduction is a key step towards understanding and managing its possible impacts on the invaded ecosystem (Herbold \& Moyle, 1986). Nevertheless, during the last decade $T$. scripta has been confirmed to reproduce in several European countries, namely in different Mediterranean countries such as Italy (Ficetola et al., 2003), France (Cadi et al., 2004) and Spain (Pérez-Santigosa et al., 2008).

In Europe, T. scripta has been reported to compete with native turtle species for basking places and food (Cadi \& Joly, 2003; 2004; Pérez-Santigosa et al., 2011). This situation is particularly alarming for the European pond turtle Emys orbicularis, which is considered as near threatened and in sharp decline in several regions of its range (IUCN, 2014), and is therefore protected by European legislation (Cox \& Temple, 2009) and subject of numerous conservation projects (e.g. Cadi \& Miquet, 2004; Lacomba \& Sancho, 2004; Ducotterd et al., 2008; Schweitzer et al., 2008; Fritz \& Chiari, 2013; Teixeira et al., 2013). In Portugal there are rising concerns about this species, since E. orbicularis is considered Endangered (Cabral et al., 2005) and coexists with the native Mediterranean pond turtle Mauremys leprosa, which may increase their spatial segregation (Segurado \& Figueiredo, 2007). So the early detection of $T$. scripta occurrence and the confirmation of its reproduction in new locations are key factors to the efficient development and implementation of adequate conservation measures and will contribute to raise the public awareness about this problematic situation.

In Portugal, at Ria Formosa Natural Park (PNRF) where M. leprosa and E. orbicularis populations coexist, $T$. scripta are sympatric. This area is populated with high densities of $M$. leprosa and contains one of the most important Portuguese populations of E. orbicularis (Cabral et al., 2005), therefore, it has been implemented a conservation project in the region in this regard (LIFE Trachemys - LIFE09 NAT/ES/000529). Here we report the widespread occurrence at PNRF and the first confirmed case of successful reproduction of $T$. scripta in the wild, in Portugal.

\section{MATERIALS AND METHODS}

The Ria Formosa Natural Park (PNRF), located in the Algarve Region (South Portugal), is a protected area including a $60 \mathrm{~km}$ stretch of the Algarve coastline and occupies an area of about 18400 hectares. Especially important because of its biological richness, it has the status of a Natural Park and is classified by the Ramsar Convention as a wetland of international interest.

From 2011 to 2013, between March and November, when the freshwater turtles activity is higher (Lebboroni \& Chelazzi, 1991; Cadi \& Joly, 2000), a set of permanent trapping techniques were implemented along four wetlands of special interest for the presence of $E$. orbicularis and M. leprosa populations: São 
Lourenço (19.6 hectares), Quinta do Lago (1.5 hectares), Dunas Douradas (1 hectares) and Garrão (0.82 hectares), located along a $5 \mathrm{~km}$ costal stretch in the Loulé council. The trapping techniques used were nine floating traps checked once a week, fourteen hoop traps checked every two days and hand nets whenever it was appropriate. All traps were distributed according to the size and shape of the water bodies, in order to evenly cover their entire area, giving six floating traps and six hoop traps at São Lourenço, two floating traps and three hoop traps at Quinta do Lago, one floating trap and three hoop traps at Dunas Douradas and two hoop traps at Garrão. The floating traps were placed in deeper areas where there were a greater number of individuals in thermoregulation or in areas with few supports for thermoregulation. The hoop traps were placed on the border of the water bodies in areas where the activity of individuals was higher and the trap could be conveniently hide. Adding to that, in order to evaluate the occurrence and abundance of $T$. scripta individuals throughout the PNRF area, visual surveys were performed every month, during the three years, around the main water bodies and streams along the Natural Park. Lastly, in July of 2013, an intensive search with a detection dog was conducted to detect nests around the São Lourenço wetland, where nesting signs were higher. This dog was trained during the LIFE Trachemys project, with the help of a specialized dog trainer, to detect eggs, juveniles or adult Trachemys specimens.

All captured individuals were measured, weighed and numbered with a four numerical code, unique to each individual, which was placed on the marginal plates of the carapace through notches realized with a small saw. The carapace length and carapace width were measured using a caliper (precision: $0.1 \mathrm{~mm}$ ) and the weight was recorded with a precision scale (precision: $0.1 \mathrm{~g}$ ). All the invasive species individuals were identified following Ernst \& Lovich, 2009 and LIFE Trachemys, 2012 and delivered on Official Reception Centers. Here, whenever evidence of eggs development were detected by inguinal palpation, females were radiographed. All $E$. orbicularis and $M$. leprosa individuals were immediately released at the capture site, after being given the individual code.

\section{RESULTS}

During the study period, we captured in the four wetlands where the trapping techniques were implemented a total of 259 individuals of different freshwater turtle invasive species, with 99 individuals being captured during the first year,

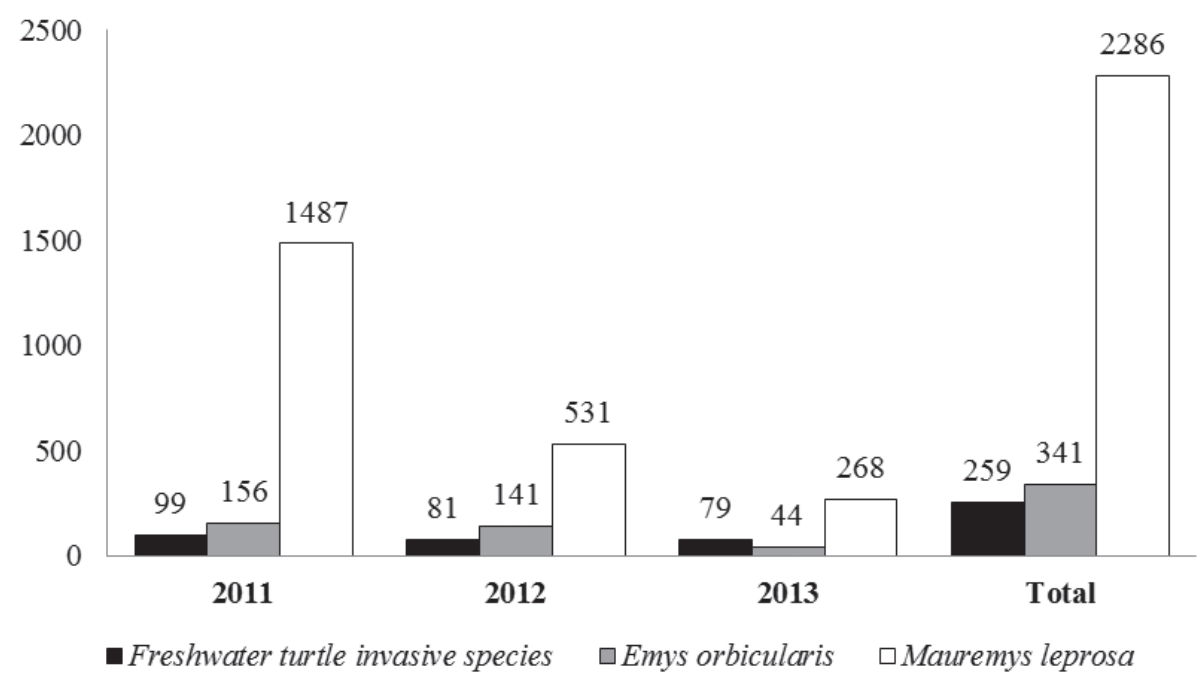

Figure 1. Total of distinct captured individuals per year from the different populations of invasive and native freshwater turtle species. Total de indivíduos distintos capturados por ano das diferentes populações de espécies invasoras e nativas de tartarugas-de-água-doce. 


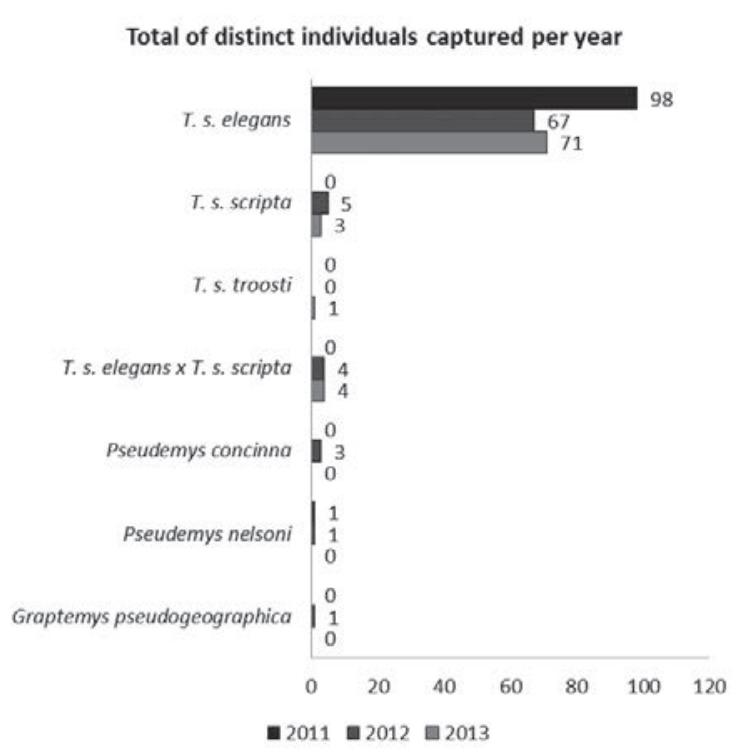

Figure 2. Total of captured individuals per year from the various invasive freshwater turtle species. Total de indivíduos capturados por ano das várias espécies invasoras de tartarugas-de-água-doce.

81 during the second year and 79 during the third year (Fig. 1). At the same time, we captured a total of 341 different individuals of E. orbicularis and 2286 of M. leprosa, with 156 E. orbicularis and $1487 M$. leprosa being captured in the first year, 141 E. orbicularis and $531 M$. leprosa in the second year and $44 \mathrm{E}$. orbicularis and $268 \mathrm{M}$. leprosa in the third year (Fig. 1). From all the captured invasive species individuals, 253 where from different sub-species of T. scripta, especially $T$. s. elegans $(\mathrm{n}=236)$, but also $T$. s. scripta $(\mathrm{n}=8), T$. s. troosti $(\mathrm{n}=1)$ and hybrids between $T$. $s$. elegans and T. s. scripta $(\mathrm{n}=8)$ (Fig. 2). The remaining individuals were Pseudemys concinna $(\mathrm{n}=3)$, Pseudemys nelsoni $(\mathrm{n}=2)$ and Graptemys pseudogeographica $(\mathrm{n}=1)$ (Fig. 2). Overall, from the captured sample, most individuals were breeding adults, especially females, together with a high number of juveniles and some hatchlings (Table 1). All hatchlings had the umbilical scar on the middle of their plastron and none had growing rings on the carapace. Among all the adult females captured, 11 T. s. elegans were egg-bearing females, identified by palpation, including one that was already covering the nest, near the border of São Lourenço wetland. The nest contained $15 \mathrm{~T}$. s. elegans eggs that we removed to prevent their future hatchling. For all the other 10 females, the X-rays revealed 17 eggs on average (minimum 15/maximum 21).

The surveys performed throughout all the Natural Park area confirmed the permanent presence of $T$. scripta populations scattered all over the Natural Park during the three years and all the estimates of observed individuals indicated the constant occurrence of hundreds of individuals (adults and juveniles) each year.

The detection dog was used for testing 4 sites, identified as more suitable for nesting near the border of São Lourenço wetland, in a total of approximately 2 hectares, with 2 visits of 1 hour/per site. One nest of T. s. elegans was detected, at the same area where most of the newly hatched nests and a female nesting during the spring were already encountered. The nest contained 14 eggs with newly hatched T. S. elegans and some still hatching, that we also removed immediately.

\section{DISCUSSION}

Our study showed that $T$. scripta occurs in high densities in the study area and confirmed for the first time the reproduction of this species in Portugal. The high number of captured and removed individuals from natural conditions, repeatedly over the three years of study, reveals an established population and the occurrence of

Table 1. Characterization of the population sample of freshwater turtle invasive species captured. Acl - Average carapace length; Acw - Average carapace width; Aw - Average weight. Caracterização da amostra da população de espécies de tartarugas-de-água-doce invasoras capturada. Acl - Comprimento médio da carapaça; Acw - Largura média da carapaça; Aw-Peso médio.

\begin{tabular}{|c|c|}
\hline \multicolumn{2}{|c|}{$\begin{array}{l}\text { Captured individuals from invasive freshwater turtle species } \\
\qquad(\mathrm{N}=259)\end{array}$} \\
\hline \multicolumn{2}{|r|}{ Adults $(\mathrm{n}=145)$} \\
\hline Females $(n=124)$ & Acl (21.2cm); Acw (16.1cm); Aw (1455.5g) \\
\hline Males $(n=21)$ & Acl $(16.7 \mathrm{~cm}) ;$ Acw $(13.0 \mathrm{~cm}) ;$ Aw $(628.8 \mathrm{~g})$ \\
\hline \multicolumn{2}{|r|}{ Juveniles $(\mathrm{n}=93)$} \\
\hline Females $(\mathrm{n}=50)$ & Acl (10.3cm); Acw (8.7cm); Aw (198.4g) \\
\hline Males $(n=36)$ & Acl $(12.7 \mathrm{~cm}) ;$ Acw $(10.2 \mathrm{~cm}) ;$ Aw (299.1g) \\
\hline Undetermined $(n=7)$ & Acl $(8.5 \mathrm{~cm}) ;$ Acw $(7.2 \mathrm{~cm}) ;$ Aw $(90.0 \mathrm{~g})$ \\
\hline \multicolumn{2}{|r|}{ Hatchlings $(\mathrm{n}=21)$} \\
\hline Undetermined $(\mathrm{n}=21)$ & Acl $(3.2 \mathrm{~cm}) ;$ Acw $(3.1 \mathrm{~cm}) ;$ Aw $(7.4 \mathrm{~g})$ \\
\hline
\end{tabular}


constant recruitment from the surroundings. The results of the surveys performed throughout the three years on the study area, support the idea of a wider distribution of the population that can provide the conditions for a successful naturalization. Adding to that, the high number of captured hatchlings, still with the presence of umbilical scar and absence of growing rings, suggest the existence of successful reproduction, since they all are smaller than the mean for T. scripta hatchlings described by Janzen et al. (2000). Furthermore, hundreds of individuals of both gender and different ages captured and observed throughout the PNRF, as well as the several adult egg-bearing females encountered near nesting sites, support the idea that they were able to adapt to the natural conditions and to establish successfully. This situation increases the direct competition with native turtles, adding a new disturbance factor and increasingly restricting the places where they occur naturally and the invasion process has not occurred yet. Lastly, the use of a detection dog for reproduction evidence, even it has not been used extensively, showed certain success, giving the location of one nest that provided evidence of reproduction of $T$. scripta and confirmed the promising application of this technique, initially developed in Australia by the Queensland Department of Natural Resources (O’Keeffe, 2005).

These results are alarming and represent a viable invasive population, co-occurring with important native populations of E. orbicularis. Without an intensive control and population management, this situation can lead to a massive and widespread naturalization of this species, with irreversible negative impacts on native fauna and on the ecosystem functioning, similarly to what has been observed in other areas throughout Europe (Cadi et al., 2004; Pérez-Santigosa et al., 2008).

Although T. scripta is very common and popular as a pet, its invasive status and impact on local ecosystems and native species are still unknown for the general public. The evidence of successful reproduction and establishment by this species in the study area might be a first sign to help rising public awareness for this problem.

Together with the successful reproduction reports of T. scripta in Spain (Martinez-Silvestre et al., 1997), Italy (Ficetola et al., 2003) and France (Cadi et al., 2004), the confirmed reproduction of T. scripta at Ria Formosa Natural Park in Portugal reinforces the possibility of permanent establishment of this species within all the Mediterranean region. This data enhances the urgent need to strengthen the European legislation, banning the trade of all T. scripta subspecies, trade control and population management by promoting an European Invasion Alert Network and early eradication campaigns from natural wetlands.

\section{ACKNOWLEDGMENTS}

This research was supported by the LIFE Trachemys project (LIFE09 NAT/ES/000529). We thank DogAlgarve, especially the dog trainer Américo Lopes and everyone who helped in the fieldwork, especially Thijs Valkenburg, Tiago Ventura, Mauro Hilário, Jael Palhas and António Cotão.

\section{REFERENCES}

BURGIN, S. 2006. Confirmation of an established population of exotic turtles in urban Sydney. Australian Journal of Zoology, 33, 379-384. DOI: 10.7882/AZ.2006.011

BUTCHART, S. H. M., M. WALPOLE, B. COLLEN, A. VAN STRIEN, J. P. W. SCHARLEMANN, R. E. A. ALMOND, J. E. M. BAILLIE, B. BOMHARD, C. BROWN, J. BRUNO, K. E. CARPENTER, G. M. CARR, J. CHANSON, A. M. CHENERY, J. CSIRKE, N. C. DAVIDSON, F. DENENER, M. FOSTER, A. GALLI, J. N. GALLOWAY, P. GENOVESI, R. D. GREGORY, M. HOCKINGS, V. KAPOS, J. F. LAMARQUE, F. LEVERINGTON, J. LOH, M. A. MCGEOCH, L. MCRAE, A. MINASYAN, M. H. MORCILLO, T. E. E. OLDFIELD, D. PAULY, S. QUADER, C. REVENGA, J. R. SAUER, B. SKOLNIK, D. SPEAR, D. STANWELL-SMITH, S. N. STUART, A. SYMES, M. TIERNEY, T. D. TYRRELL, J. C. VIÉ \& R. WATSON. 2010. Global Biodiversity: Indicators of Recent Declines. Science, 328: 1164-1168. DOI: 10.1126/science.1187512 CABRAL, M. J., J. ALMEIDA, P. R. ALMEI- 
DA, T. DELLLINGER, N. FERRAND DE ALMEIDA, M. E. OLIVEIRA, J. M. PALMEIRIM, A. I. QUEIROZ, L. ROGADO \& M. SANTOS-REIS. 2005. Livro Vermelho dos Vertebrados de Portugal. Instituto da Conservação da Natureza. Lisboa. Portugal.

CADI, A. \& P. JOLY. 2000. The introduction of the slider turtle (Trachemys scripta elegans) in Europe: competition for basking sites with the European pond turtle (Emys orbicularis). Proceedings 2nd International Symposium on Emys orbicularis. Chelonii, 2: 95-100.

CADI, A. \& P. JOLY. 2003. Competition for basking places between the endangered European pond turtle (Emys orbicularis galloitalica) and the introduced red-eared slider (Trachemys scripta elegans). Canadian Journal of Zoology, 81: 1392-1398. DOI: 10.1139/z03-108

CADI, A. \& P. JOLY. 2004. Impact of the introduction of the red-eared slider (Trachemys scripta elegans) on survival rates of the European pond turtle (Emys orbicularis). Biodiversity and Conservation, 13: 2511-251. DOI: 10.1023/B:BIOC.0000048451.07820.9c

CADI, A. \& A. MIQUET. 2004. A reintroduction programme for the European pond turtle (Emys orbicularis) in Lake Bourget (Savoie, France): First results after two years. Biologia, 59: 155-159.

CADI, A., V. DELMAS, A. C. PREVOT-JULLIARD, P. JOLY, C. PIEAU \& M. GIRONDOT. 2004. Successful reproduction of the introduced slider turtle (Trachemys scripta elegans) in the south of France. Aquatic Conservation: Marine and Freshwater Ecosystems, 14: 237-246. DOI: 10.1002/aqc.607

CHEN, T-H. \& K-Y. LUE. 1998. Ecological notes on feral populations of Trachemys scripta elegans in northern Taiwan. Chelonian Conservation and Biology, 3: 87-90.

COX, N. A. \& H. J. TEMPLE. 2009. European Red List of Reptiles. Luxembourg: Office for Official Publications of the European Communities.

DUCOTTERD, J. M., D. MOSIMANN \& A. CADI. 2008. European pond turtle (Emys orbicularis) conservation program in Switzerland. Revista Española de Herpetología, 22: 115-119.
ERNST, C. H. \& J. E. LOVICH. 2009. Turtles of the United States and Canada. Johns Hopkins University Press.

FICETOLA, G. F., A. MONTI \& E. PADOA SCHIOPPA. 2003. First record of reproduction of Trachemys scripta in the Po Delta. Annali del Museo Civico di Storia Naturale di Ferrarra, 5: 125-128.

FRITZ, U. \& Y. CHIARI. 2013. Conservation actions for European pond turtles - a summary of current efforts in distinct European countries. Herpetology Notes, 6: 105.

HERBOLD, B. \& B. P. MOYLE. 1986. Introduced species and vacant niches. The American Naturalist, 128: 751-760.

HULME, P. E., P. PYSEK, W. NENTWIG \& M. VILA. 2009. Will threat of biological invasions unite the European Union?. Science, 324: 40-41. DOI: 10.1126/science.1171111

IUCN. 2014. The IUCN Red List of Threatened Species. Version 2014.2. <http://www.iucnredlist.org >. Downloaded on 24 July 2014.

JANZEN, F. J., J. K. TUCHER \& G. L. PAUKSTIS. 2000. Experimental analysis of an early life-history stage: selection on size of hatchling turtles. Ecology, 81(8): 2290-2304. DOI: 10.1890/0012-9658(2000)081[2290:EAO AEL]2.0.CO;2

LACOMBA, A. I. \& A. V. SANCHO. 2004. Advances in the action plan for Emys orbicularis in the Valencia region, Spain. Biologia, 59: 173-176.

LEBBORONI, M. \& G. CHELAZZI. 1991. Activity pattern of Emys orbicularis (Chelonia Emydidae) in central Italy. Ethology Ecology \& Evolution, 3: 257-268. DOI: 10.1080/08927014.1991.9525373

LIFE Trachemys. 2012. Guía metodológica para la captura y manejo de galápagos. Informe LIFE Trachemys $n^{\circ} 8$. Conselleria d'Infraestructures, Territori i Medi Ambient, 39pp.

LOWE, S., M. BROWNE, S. BOUDJELAS \& M. DE POORTER. 2000. 100 of the World's Worst Invasive Alien Species: A selection from the Global Invasive Species Database. The Invasive Species Specialist Group (ISSG) of the World Conservation Union (IUCN).

LUISELLI, L., M. CAPULA, D. CAPZZI, E. PHILIPPI, V. TRUJILLO JESUS \& C. ANI- 
BALDI. 1997. Problems for conservation of pond turtles (Emys orbicularis) in central Italy: is the introduced red-eared turtle (Trachemys scripta) a serious threat?. Chelonian Conservation and Biology, 2: 417-419.

MARTINEZ-SILVESTRE, A., J. SOLER, R. SOLE, F. X. GONZALEZ \& X. SAMPERE. 1997. Nota sobre la reproducción en condiciones naturales de la tortuga de Florida (Trachemys scripta elegans) en Masquefa (Cataluna, Espana). Boletín de la Asociación Herpetológica Española, 8: 40-43.

MIRANDA, R. \& P. M. LEUNDA. 2010. Updated status and management of non-native freshwater species in the Iberian Peninsula. Aquatic Invasions, 5 (3): 229-230. DOI: 10.3391/ai.2010.5.3.01

MOONEY, H. A., R. N. MACK, J. A. MCNEELY, L. E. NEVILLE, P. J. SCHEI \& J. K. WAAGE. 2005. Invasive Alien Species: a New Synthesis. Island Press, Washington, DC, USA.

NEWBERRY, R. 1984. The American red-eared terrapin in South Africa. African Wildlife, 38: 186-189.

O'KEEFFE. 2005. Investing In Conjecture: Eradicating the Red-Eared Slider In Queensland. 13th Australasian Vertebrate Pest Conference Proceedings. Pp 169-175.

PÉREZ-SANTIGOSA, N., C. DÍAZ-PANIAGUA \& J. HIDALGO-VILA. 2008. The reproductive ecology of exotic Trachemys scripta elegans in an invaded area of southern Europe. Aquatic Conservation: Marine and Freshwater Ecosystems, 18: 1302-1310. DOI: 10.1002/aqc.974
PÉREZ-SANTIGOSA, N., M. FLORENCIO, J. HIDALGO-VILA \& C. DÍAZ-PANIAGUA. 2011. Does the exotic invader turtle, Trachemys scripta elegans, compete for food with coexisting native turtles?. Amphibia-Reptilia, 32(2): 167-175(9). DOI: 10.1163/017353710 X552795

PRIMACK, R. B. 1997. Essentials of Conservation Biology. Sinauer Associates. Sunderland Mass.

SCHWEITZER, S., R. PRINZINGE \& R. WICKER. 2008. Reintroduction project of the turtle Emys orbicularis in Hesse (Germany): basic steps and first results. Revista Española de Herpetología, 22: 121-130.

SEGURADO, P. \& D. FIGUEIREDO. 2007. Coexistence of two freshwater turtle species along a mediterranean stream. Acta Oecologica, 32 (2007): 134 - 144. DOI: 10.1016/j.actao. 2007.03.015

TEIXEIRA, J., B. H. MARTINS, J. PALHAS, A. ALVES \& F. AZEVEDO. 2013. Conservation activities for European pond turtles (Emys orbicularis) in Portugal. Herpetology Notes, 6: 153-155.

TELECKY, T. M. 2001. United States import and export of live turtles and tortoises. Turtle and Tortoise Newsletter, 4: 8-13.

THOMSON, R. C., P. Q. SPINKS \& H. B. SHAFFER. 2010. Distribution and Abundance of Invasive Red- Eared Sliders (Trachemys scripta elegans) in California's Sacramento River Basin and Possible Impacts on Native Western Pond Turtles (Emys marmorata). Chelonian Conservation and Biology, 9 (2): 297-302. DOI: 10.2744/CCB-0820.1 